\title{
The impact of 'stop-go' demand management policy on Britain's consumer durables industries, 1952-65
}

Article

Accepted Version

Scott, P. M. and Walker, J. T. (2017) The impact of 'stop-go' demand management policy on Britain's consumer durables industries, 1952-65. The Economic History Review, 70 (4). pp. 1321-1345. ISSN 0013-0117 doi:

https://doi.org/10.1111/ehr.12470 Available at https://centaur.reading.ac.uk/71309/

It is advisable to refer to the publisher's version if you intend to cite from the work. See Guidance on citing.

Published version at: http://dx.doi.org/10.1111/ehr.12470

To link to this article DOI: http://dx.doi.org/10.1111/ehr.12470

Publisher: Wiley

All outputs in CentAUR are protected by Intellectual Property Rights law, including copyright law. Copyright and IPR is retained by the creators or other copyright holders. Terms and conditions for use of this material are defined in the End User Agreement.

www.reading.ac.uk/centaur 
Central Archive at the University of Reading

Reading's research outputs online 


\title{
The impact of 'stop-go' demand management policy on Britain's consumer durables industries, 1952 - 1965
}

\section{Peter M. Scott and James T. Walker}

International Business and Strategy, Centre for International Business History, Henley Business School, University of Reading

\begin{abstract}
We examine the impacts of British government 'stop-go' policy on domestic sales of consumer durables over 1952 - 1965, via hire purchase restrictions and punitive Purchase Tax rates. Our analysis includes a general review of contemporary evidence regarding the impacts of these measures, a more detailed study of the television sector, and time-series econometric analysis for both televisions and a representative highticket labour-saving consumer durable -washing machines. We find that the restrictions had devastating impacts on Britain's consumer durables industries, preventing firms from fully exploiting economies of scale, reducing output growth and international competitiveness, and eroding industrial relations. Government officials were aware of these problems, but considered them a price worth paying to facilitate moves towards sterling convertibility and the re-establishment of the City as a leading financial and trading centre.
\end{abstract}


From 1952 successive British governments used hire purchase (HP) restrictions and Purchase Tax on consumer durables as key instruments of consumer demand management. ${ }^{\mathrm{i}}$ During the 1950s and early 1960s policy interventions were particularly severe, with the periodic imposition of tight HP controls and Purchase Tax rates of up to 66.67 per cent. These had reinforcing impacts, principally through raising the upfront 'price' facing the credit purchaser (the minimum HP deposit payment) - and were regarded by policy-makers as close substitutes. ${ }^{\text {ii }}$

While sometimes presented as an instrument of employment stabilisation, a key driver of demand management policy during this period was an over-riding priority among an influential section of policy-makers to restore sterling as a 'strong' currency (second only to the dollar) and re-establish the City as a major financial and trading centre, despite heavy wartime debts and low currency reserves. There has been substantial debate regarding whether this prioritisation of external stability over internal stability had a detrimental impact on British economic growth and industrial output. ${ }^{\text {iii }}$ We focus more narrowly on the impact of stop-go on those industries primarily impacted by the HP and Purchase Tax restrictions - motor vehicles and household durables.

Although they represented only about eight per cent of consumer expenditure by the early 1960s (and 12.0 per cent of 1963 manufacturing net output), consumer durables shouldered the main burden of consumption restrictions. ${ }^{\text {iv }}$ As an official working party noted laconically, these controls operated on "such a narrow front [that] big changes in the controls have to be applied in order to produce the required change in demand. This produces great disturbances in the industries affected as well as great uncertainty." "v The Treasury and Bank of England viewed consumer durables as relatively low priority sectors, as their ratio of exports to total sales was lower than for the staple industries - reflecting protectionism and different 
market requirements (such as alternative standards for mains voltages or television frequencies, or road conditions favouring higher horsepower cars). ${ }^{\mathrm{vi}}$

However, in other respects these were important sectors. Rapid household diffusion of consumer durables in most western nations, together with falling unit costs owing to rapid process innovations and scale economies, made them important growth industries. ${ }^{\text {vii }}$ Even in Britain (where government systematically restricted their growth during 'stop' phases of the economic cycle), gross output in the electrical appliances sector rose from $£ 72$ million in 1954 to $£ 312$ million in 1970 ; while gross output in motor vehicles expanded from $£ 883$ million to $£ 3,306$ million. ${ }^{\text {viii }}$ Meanwhile the television and radio sector not only witnessed relatively rapid growth, but formed the bedrock of the wider electronics industry. Yet these characteristics also made them extremely vulnerable to unpredictable cuts in demand, which prevented plants from approaching full capacity and, in some sub-sectors subject to rapid product innovation, such as televisions, could lead to build-ups of excessive stocks that might become obsolete before the restrictions were lifted.

This article examines the extent to which stop-go policies contributed to the declining international competitiveness of these sectors. The first section outlines the evolution of government policy and the chronology of stop-go during the 1950s (which witnessed the greatest volatility in policy). We then examine contemporary evidence regarding the impacts of the restrictions, finding that they were widely perceived to have reduced potential scale economies; depressed both home and export sales; created a cycle of short-time working or lay-offs followed by systematic overtime, which eroded industrial relations; and produced a climate of extreme uncertainty that wreaked havoc with long-term production planning and investment. We look in more detail at the major new 'consumer durables boom' product of this era, televisions, to determine whether firms were seeking to serve post-war demand through mass production and whether the restrictions thwarted these efforts. Finally, we undertake a 
quantitative analysis of the relationships between the policy restrictions and sales growth, for televisions and a representative high-ticket 'labour saving' durable, washing machines.

\section{I}

After 1951 Britain only suffered balance of payments deficits in two of the following ten years (1955 and 1960). However, the pursuit of policies designed to restore Britain's international economic role, and the City's status as a leading financial and trading centre, led to strong conflicts between domestic industrial growth and external stability. Restoring the City's international status was perceived to require the resumption of sterling as a strong convertible currency with a major international role, an openness to capital inflows (including 'hot money'), substantial outward investment in the sterling area, and efforts to maintain Britain's great power status through historically high peacetime levels of defence expenditure (reflected in persistent public sector current account deficits). ${ }^{\text {ix }}$ Given its low currency reserves, these policies made Britain particularly vulnerable to sterling crises (which, in practice, limited the extent to which they could be realised). ${ }^{\mathrm{x}}$ Maintaining confidence in sterling under these conditions was deemed to require periodic 'credit squeezes' to dampen inflationary pressures and demonstrate Britain's prioritisation of external stability over domestic needs. ${ }^{\mathrm{xi}}$

Squeezing consumer spending was achieved principally through restricting HP terms on consumer durables and raising their Purchase Tax rates. Purchase Tax had been introduced in 1940 as a war-time sales tax, for revenue and resource control purposes. On administrative convenience and cost grounds it was levied at the wholesale, rather than retail, stage. Purchase Tax became increasingly focused on consumer durables during the War period and the postwar austerity era and remained so thereafter. ${ }^{\text {xii }}$

The Conservatives' 1951 election campaign focused on Labour's severe restrictions on consumption, promising an end to austerity. ${ }^{\text {iii }}$ Following their victory the proportion of consumer expenditure subject to overt rationing fell from 10 per cent in 1951 to 2 per cent in 
1955. ${ }^{\text {xiv }}$ However, the use of less obvious means of 'rationing' (through the price mechanism), such as HP restrictions and Purchase Tax, intensified. At a January 1952 meeting of Commonwealth Finance Ministers the new government included HP restrictions among a package of proposals aimed at stemming the loss of Britain's dollar reserves. These restrictions were introduced in the 1952 budget. ${ }^{\mathrm{xv}}$ Labour had already raised Purchase Tax on consumer durables from $331 / 3$ to $662 / 3$ per cent in the 1951 budget, to divert resources to defence and exports. ${ }^{\text {xvi }}$ The HP restrictions thus accentuated the increased pressure on these sectors. The Chancellor, Rab Butler, justified them as a means of saving scarce resources, but added that, 'hire purchase... is essentially a form of living beyond one's means. ${ }^{\text {xvii }}$ However, prudential arguments for HP terms control (to protect either the debt burden on consumers or the solvency of HP finance houses) did not feature in the deliberations preceding this, or subsequent, HP restrictions. When this issue was addressed, by an Inter-Departmental Group in December 1959, it was concluded that no convincing prudential case could be made for terms control. ${ }^{\text {xiii }}$

Minimum down-payments of one third of the purchase price and maximum contract lengths of 18 months were imposed for a variety of goods including radios, household durables, and motor cycles. Automobiles required a similar minimum deposit, but with 30 months to pay, while bicycles had a 25 per cent minimum down-payment and a 12 month minimum term. ${ }^{\text {xix }}$ This set the broad parameters of HP controls for the rest of the decade - largely on the basis of redundant Korean War defence considerations. As a 1954 Treasury memorandum noted, "the list of goods at present controlled has been arrived at rather by historical accident... the supply position of metals and other scarce raw materials; it is doubtful whether the list in its present form really includes the right goods for the purposes of controlling consumers' expenditure." ${ }^{\mathrm{xx}}$ 
The Bank of England (with some support from the Treasury's Overseas Finance Division) regarded HP restrictions and Purchase Tax as a particularly useful tools of 'financial repression' to cut consumer demand at any given interest rate. They formed part of a panoply of measures designed to restrict domestic credit and consumption, including controls on new capital issues and various measures to restrict bank lending. ${ }^{\mathrm{xxi}}$ These assisted a policy of sterling liberalisation, that required domestic demand to be periodically depressed in order to avoid runs on sterling - given Britain's large overseas sterling balances, in conjunction with high levels of capital outflow and overseas government expenditure. ${ }^{\text {xii }}$ This was bluntly summarised in a July 1952 note from the Bank of England Governor, Cameron Cobbold, to the Chancellor, Rab Butler: 'responsibility for sterling lies with the Government... HMG must demonstrate that they are resolved to do whatever is necessary to discharge that responsibility. They can only demonstrate that by action taken at home where sterling has its foundations. ${ }^{\text {xxiii }}$

The Bank proved successful in pushing this agenda. Indeed it was so confident that the burden of any pressure on sterling would be addressed through depressing domestic demand that, without international support, it moved to substantially liberalise controls on the transferability of external sterling holdings in March 1954, while also re-opening the London gold market; paving the way for de facto current account convertibility from February 1955 . $^{\text {xiv }}$ By May 1954 the Treasury accepted that they had no legitimate defence or supply grounds for restricting domestic sales of consumer durables, but justified restriction as an administratively easy and effective means of depressing consumer demand, while also emphasising the revenue generated from high Purchase Tax rates. ${ }^{\mathrm{xx}}$ Meanwhile evidence of damaging impacts on the consumer durables sectors was routinely brushed aside. For example, a March 1953 Treasury memorandum noted that most of these industries had a strong case for relief, but added: 
On the other hand, reduction of the Purchase tax on passenger cars from $662 / 3 \%$ to 33 $1 / 3$ per cent would almost certainly have to be accompanied by concessions on domestic appliances, which have been much harder hit, and possibly also on radio and television as well. All of this would add up to a considerable sum... ${ }^{\text {xxvi }}$

As a result, these sectors continued to bear the brunt of the Purchase Tax burden. Furniture, domestic appliances, audio-visual equipment, and road vehicles, raised $£ 270.8$ million (gross) in 1958, representing 54 per cent of the total Purchase Tax yield. ${ }^{\text {xxvii }}$

HP regulations were suspended in July 1954, but reintroduced in February 1955. They were then tightened substantially in July 1955 and again in February 1956, in an effort to quell inflationary pressures - reinforced by an expansionary budget on the eve of the 1955 election. ${ }^{\text {xxvii }}$ Controls were also extended to furniture, which had hitherto typically been sold on very long HP contracts, with extremely low minimum deposits. This had a dramatic impact, furniture sales falling by some 50 per cent between the second and third quarters of 1954 and the same period in $1955 .^{\text {xix }}$

A 1957 working party of economists drawn from the members of the Federation of British Industries [FBI] concluded that HP restrictions had been mis-timed, being lifted in 1954 when a HP boom was already developing, then tightened in 1956, when the market was already showing signs of contraction. They also hypothesised that HP restrictions might "bunch" groups of HP customers together, in a way that would accentuate market volatility (by, for example, creating a large supressed demand). ${ }^{\mathrm{xx}}$ These problems persisted. On $15^{\text {th }}$ September 1958, with sterling strong and recession looming, HP controls were relaxed. Then on October $29^{\text {th }} 1958$ all HP restrictions were abolished. HP finance houses and retailers responded by reducing minimum deposit requirements and extending contract periods, releasing considerable pent-up demand, with some retailers running out of stock. ${ }^{\mathrm{xxxi}}$ 
However, liberalisation was short-lived. The Chancellor had responded to rising unemployment and a strong balance of payments in 1959 by what proved to be a recklessly expansionist budget that (like many economic adjustments of the period) came too late in the economic cycle to have the desired impact. ${ }^{\text {xxii }}$ In consequence HP controls were re-imposed at the end of April 1960. Between the third quarters of 1959 and 1960 new consumer instalment credit for durable goods fell from $£ 194$ million to only $£ 140$ million. ${ }^{\text {xxxiii }}$ Even the Treasury (which typically sought to downplay adverse impacts) privately acknowledged that, 'The situation is potentially a serious one. On the assumptions that retail sales remain around their present level (allowing for seasonal variations) and that between now and August 1961 stocks are reduced to the level existing in August 1958... production in the next twelve months would be at a rate $40-50 \%$ lower than the levels to which it had been reduced in July and August.' ${ }^{\text {xxxiv }}$ In May 1960 the Board of Trade estimated that a reduction in HP debt of $£ 115$ million (compared to its March 1960 value of $£ 920$ million) would be consistent with a contraction of sales for consumer durables (excluding cars, which were partially protected in the short-term by the use of trade-ins for deposits) of around 70 per cent. ${ }^{\mathrm{xxx}}$

HP and Purchase Tax continued to be used for macroeconomic stabilisation during the 1960s, though fluctuations in controls were generally less dramatic. For example, while minimum HP deposits for cars had varied between zero and 50 per cent during the 1950s, from April 1960 to June 1966 they varied only between 20 and 25 per cent. ${ }^{x x v i}$

\section{II}

Consumer durables manufacturers and retailers resented what they saw as the arbitrary designation of their sectors for demand management, but were particularly aggrieved by the sudden and unanticipated changes to HP restrictions and Purchase Tax rates, that played havoc with production schedules. Officials were aware that these sectors were particularly reliant on 
mass production to lower unit costs and sustain international competitiveness. As a Board of Trade paper noted, consumer credit was vital to this strategy: "The high technical efficiency of the United States... in... motor cars, refrigerators, and other domestic appliances could probably not have been achieved so rapidly without the aid of hire purchase..."xxxvii

However, such arguments cut no ice with policy-makers who subordinated the needs of domestic industry to their major long-term aims of defending sterling and restoring Britain to its former status as a leading financial and trading nation. The consumer durables' sectors thus persistently failed to secure a stable tax and HP regulation framework suitable for mass production, or even long-term planning. As a June 1960 FBI memorandum noted, 'production over the past decade in the domestic appliance industry, which is particularly vulnerable to such [credit restriction] measures, presents a bewildering pattern, reflecting the violent changes in demand... with slumps following booms in seemingly endless rotation... Artificial booms... created by the release of pent-up demand, are as much to be deplored as slumps. ${ }^{\text {xxxviii }}$

As Wray noted, the 1955 and 1956 credit control measures had curtailed production only at the cost of considerable difficulties for the firms concerned, 'who have been left to meet the problem of adjusting their labour forces, production schedules, stocks of raw materials and components, and forward commitments, to a sudden contraction in their markets. ${ }^{\text {xxxix }}$ Government officials also privately acknowledged this. A 1963 working party on HP controls noted that when controls were lifted production could not be expanded quickly enough to meet pent-up demand, leading to a boom in imports. Conversely, additions to capacity to meet rising demand could prove worthless following their unanticipated re-imposition. ${ }^{\mathrm{xl}}$ Instability in demand was also said to have reduced scale economies, by deterring investment and fostering a bias towards labour-intensive production methods, which were more flexible to violent and unanticipated demand fluctuations. ${ }^{\text {xli }}$ 
One notable victim of the various credit squeezes was the motor vehicle industry, which accounted for almost one million workers in 1960 (including components, garage, and repair servicing), around 5 per cent of industrial production, and 16 per cent of UK visible exports. ${ }^{\text {xlii }}$ In addition to very strict HP controls compared to overseas producers, 60 per cent Purchase Tax on the wholesale price of cars (equivalent to around 50 per cent of the retail price) was far higher than the sales taxes on cars imposed by the major European car-producing nations in 1957 (6 per cent in Germany; 7 per cent in Italy; and 24 per cent in France), while the burden of other car taxes was also high by international standards. ${ }^{\text {liii }}$

In September 1952 the Society of Motor Manufacturers and Traders [SMMT] had reported to government that the industry was working at only 60 per cent of capacity as a result of the HP restrictions and Purchase Tax hike, resulting in redundancies and widespread shorttime working. ${ }^{\text {xliv }}$ Treasury officials disputed whether industry sales were below the level required for the home market, but did so using rather extreme assumptions (one analysis assumed a static national stock of cars at pre-war levels and an average vehicle lifetime of 1520 years - compared to the eight year lifespan commonly assumed in the 1930s). ${ }^{\mathrm{xlv}}$

The 1955-56 HP restrictions also had a severe impact on this sector. By early March 1956 several major producers had introduced short-time work, affecting some 20,000 employees. ${ }^{\text {xlvi }}$ Car manufacturers pressed for a reduction in Purchase Tax - as this had a more immediate impact on the new car market (where trade-ins often covered deposits). In 1957 Ford estimated that home sales of British cars were around 25 per cent less (and overall production 14 per cent less) owing to Purchase Tax - sufficient to increase British unit production costs by at least 10 per cent. ${ }^{\text {xlvii }}$

The 1960 HP restrictions produced another severe downturn. Car production fell from 405,000 units in the second quarter to 243,000 in the fourth quarter, while home demand declined from 247,500 to 139,000 , with widespread short-time working by the end of the 
year. ${ }^{\text {xlviii }}$ However, government made it clear that credit controls and Purchase Tax would be eased only when justified by the general economic situation. ${ }^{\text {xlix }}$ Representations by the SMMT again emphasised the burden of 50 per cent Purchase Tax, claiming that progressive reductions to 16 per cent by 1963 would reduce unit costs by $7-10$ per cent (a major saving, relative to the small margins on which cars were sold) and increase the industry's employment by more than a quarter. ${ }^{1}$ Similar problems were evident for other consumer durables. In September 1960 the FBI's Director-General informed the Board of Trade that HP controls had disrupted production schedules and raised unit costs, domestic sales of leading household appliance manufacturers having fallen by as much of 30-40 per cent. ${ }^{\text {li }}$ Tariff protection cushioned the industry from the full competitive impacts of the higher production costs imposed by periodic squeezes on their domestic sales - though their cumulative productivity impacts left firms extremely vulnerable to any initiatives, such as EFTA or EEC membership, that might remove this protection. ${ }^{\text {lii }}$

Consumer durables manufacturers traditionally encouraged dealers to hold significant stocks, to smooth seasonal demand fluctuations and aid production planning. However, changes in HP regulations or Purchase Tax rates threatened to slash the value of dealers' stocks. Retailers thus increasingly adopted a lean, 'just in time', approach to ordering, rather than working cooperatively with manufacturers. ${ }^{\text {liii }}$ Whitehall made little effort to ameliorate their difficulties. For example, despite initial assurances that a mechanism would be devised for refunding Purchase Tax to retailers with stocks that had been charged higher tax when conveyed to them, officials failed to do so, claiming that it had not proved possible to find an administratively convenient and fraud-proof means, while repeatedly rejecting any mechanisms proposed by retailers. ${ }^{\text {liv }}$

One standard Treasury response to industry complaints involved exhortations to focus on exports. In fact, HP restrictions were widely regarded as acting to depress exports and (during boom phases of the stop-go cycle) encourage imports. Domestic producers lacked the 
capacity to meet the sudden surges in demand when controls were eased. For example, the removal of HP restrictions in 1958 led to a boom that overshot the capacity of domestic producers and precipitated a surge in imports of domestic appliances, which rose in value by 82 per cent over the year following liberalisation. By summer 1960 imports of these goods stood at some eight times the level of $1955 .^{\text {lv }}$ Similar impacts were identified for Purchase Tax; for example, in 1954 Soloway concluded that its use to switch sales from home to export markets had depressed output below cost-effective mass production levels. ${ }^{\text {lvi }}$ A Board of Trade study also found that contracting home demand depressed exports - by increasing unit costs and slowing new model development. ${ }^{\text {lvii }}$

HP restrictions and Purchase Tax also distorted home demand in favour of lower model standards, often unsuitable for export markets. For example, these were said to have delayed the acceptance of the more expensive 21 inch screen TV format in Britain during the late 1950s, whereas in the USA and Europe 21 inch and larger screens were standard. Pressure to provide lower-cost sets also led British manufacturers to produce models of less attractive cosmetic design and fewer "features" than were demanded in major overseas markets. ${ }^{\text {lviii }}$

Despite this evidence, Treasury officials took comfort in the buoyant state of national employment. ${ }^{\text {lix }}$ However, within the affected industries the restrictions were having substantial negative impacts on employment, labour productivity, and labour relations. As noted above, 'stop' phases saw major contractions in employment. For example, employment in furniture and upholstery fell from 142,000 in 1954 to 125,700 by April $1958 .{ }^{1 x}$ Moreover, in the domestic appliances and motor vehicle sectors unemployment was partially disguised by hoarding skilled labour. ${ }^{1 x i}$ Then in boom phases firms were often forced to rely extensively on overtime to meet orders, given their depressed capacity. As a 1960 FBI memorandum noted, when controls were eased the resulting spikes in production fostered, 'exceptionally high earnings accentuated by incentives and overtime which... inculcates a sense of false values and creates 
a most difficult situation when earnings are subsequently depressed... it is virtually impossible to maintain good relations, sound incentive schemes, or to organise satisfactory training and promotion if the company is forced by violent changes in demand to a policy of "hire and fire". lxii

Historical studies corroborate claims that stop-go was an important factor fostering labour militancy. ${ }^{\text {xiii }}$ This is also corroborated by official data on 'substantial' strikes, each involving more than 5,000 working days. The peak years for automobile strikes attributed to redundancies or short-time working $(1953,239,000$ working days, one strike commencing February; 1956, 241,000 working days, three strikes, one commencing late April and two in July); and 1960, 66,800 working days, six strikes commencing between March and December), coincide strongly with the peaks of the three credit squeezes. Meanwhile annual working-days lost through strikes attributed to redundancies/short-time averaged only 23,667 over $1950-52$, zero over $1954-55$, and 1,867 over 1957-59). ${ }^{\text {lxiv }}$

Analysis of the impact of stop-go on relative productivity must account for national differences in product characteristics, such as car sizes. Again, data are largely restricted to cars. Britain was transformed from having the highest automobile productivity in Europe (and second only to the USA) in 1955 to ranking below West Germany, Italy, and France by 1965, with Britain's relative productivity continuing to decline over the next decade. This was accompanied by slower output growth after 1955, relative to Britain's European competitors. ${ }^{1 \mathrm{xv}}$ The declining competitiveness of Britain's motor vehicle industry (which also includes factors not captured in productivity measures, such as poor styling or reliability) is also reflected in a sharp fall in its share of world trade in cars over the 1950s and 1960s. ${ }^{\text {lxvi }}$

Britain's declining relative productivity in automobiles is, in turn, linked to its progressive failure to achieve minimum efficient scale of output (estimated, at the firm level, to have risen rapidly from 150,000 units in 1947 to 750,000 in 1960 , driven by rapid process 
innovation). ${ }^{\text {lxvii }}$ Unanticipated cuts in home demand were particularly damaging, by restricting output far below capacity levels, with substantial impacts on production costs. ${ }^{\text {xviii }}$ This is corroborated by research showing that the volatility of British automobile production was markedly higher than that for major European producers, especially in relation to the industry's growth rate. ${ }^{1 x i x}$

Demand restrictions also impacted heavily on consumers, especially working-class households. It was estimated in 1959 that British consumer HP debt amounted to around $£ 12$ per capita, a much lower figure than in the USA (£49), Australia (£32) or Canada (£33). ${ }^{\text {lxx }}$ This translated into an unusually low diffusion of consumer durables (given Britain's high per capita incomes). For example, in 1957 less than 10 per cent of British homes had refrigerators, compared to 12 per cent in France, 14 per cent in West Germany, 25 per cent in Denmark, 26 per cent in New Zealand and 50 per cent or more in Sweden, Australia, Canada, and the USA..$^{\text {.xxi }}$ Officials privately recognised that HP restrictions were discriminatory in that they mainly targeted working-class customers, 'suddenly making it more difficult for poor people to obtain goods... when the same goods were readily available to people able to pay cash', or to white collar workers with access to bank loans or department store accounts. ${ }^{\text {lxxii }}$

\section{III}

To explore these impacts in more detail, this section focuses on a particular product class. Televisions are chosen as they were a high priority durable; lacked a significant trade-in market to cover deposits (owing to short lifespans and rapid technical obsolescence, driven by rising screen sizes) unlike, for example, motor vehicles; and were an expensive item throughout this period, with all models priced well above the normal ceiling for cash purchases. However, they were typical of household durables in terms of their HP restrictions and Purchase Tax rates. 
Britain had been a leading television pioneer, with the world's first regular high definition television service, from 1936. Surviving firm-level evidence indicates that during the early post-war years leading manufacturers were committed to mass production. For example, Ferranti adopted a mass production strategy after comparing current production costs with American data on unit costs at higher production levels (see Table 1). This involved setting prices at initially loss-making levels, to achieve long production runs and, therefore, scale economies in what was anticipated to be a rapidly expanding market. ${ }^{\text {lxxiii }}$ EMI followed a similar strategy, launching a project to produce the cheapest TV set on the market (to sell at $£ 45$, inclusive of current Purchase Tax) in 1948. This would involve a production cost of $£ 15$, which was believed possible only on a production run of at least 100,000 . However, owing to the government restrictions EMI repeatedly found itself left with obsolete stock of each production run, which it had been unable to sell before the next generation of models became available..$^{\text {xxiv }}$

\section{[Table 1 near here]}

The imposition of a one third minimum deposit and 18 months maximum HP contract term in the 1952 budget substantially narrowed the market for televisions, given that the cheapest cost around $£ 60$, including Purchase Tax, (equivalent to almost seven weeks’ earnings for average male industrial workers aged 21 or over). ${ }^{1 \mathrm{xxv}}$ The Chancellor had recommended that during 1952 the value of radio and TV output should be cut by 25 per cent - to redeploy production capacity to defence needs. However, the HP restrictions produced an output reduction of about 40 per cent compared to the previous year, while even a 25 per cent reduction was estimated to inflate unit costs by $7.5-10$ per cent. ${ }^{1 x x v i}$

Following the 1953 Purchase Tax reduction a new 'go' phase ensued, with demand exceeding capacity and shortages developing (compounded by a shift of demand from 9 and 12 inch screens to 14 and 15 inch sets which sold at the price charged for the smaller sets prior 
to the Purchase Tax cut). G.E.C. was rumoured to have 4,000 sets awaiting tubes and retailers reported having to wait 4-6 weeks for sets and considerably longer for tubes and repairs. ${ }^{\text {lxxvii }}$ The growth in sales was accompanied by an increase in the proportion of TV's sold on HP, from 45.1 per cent in July 1953 to 66.4 per cent in July 1954 . ${ }^{\text {lxxviii }}$

In the mid-1950s over 30 British TV brands were being marketed, by around 20 different business groups (with independent design, production, and distribution facilities). The second half of the decade witnessed significant consolidation. Yet what could have been a beneficial process was undermined by financial crises among some of the largest and most dynamic firms - precipitated by 'stop' phases of the HP/Purchase Tax cycle. ${ }^{\text {lxix }}$ Some major manufacturers with broader interests made strategic decisions to quit the sector, to shield themselves from its instability. For example, in 1957 EMI ceased making receivers for the domestic market, with Ferguson taking over their brands. ${ }^{\operatorname{lxx}}$ Another leading manufacturer, Pye, which was much more focused on televisions and radios, sought to develop subsidiaries outside this sector, to minimise the impacts of what its chief executive, C.O. Stanley, described as the "terrible peaks and dips" in sales. .xxxi $^{\text {. }}$

Until the late 1950s television was a "growth" industry, with a substantial proportion of first-time buyers and demand boosted by extensions of the broadcasting day, the launch of ITV, the spread of transmission coverage, and the introduction of larger set formats. However, by the end of 1958 both the BBC and ITV had achieved virtually national coverage and around two thirds of British homes had sets. The onset of market 'maturity' was masked by a government-induced boom from November 1958 to the last quarter of 1959, arising from the removal of credit restrictions and a reduction in Purchase Tax from 60 to 50 per cent in the 1959 budget. These measures boosted diffusion and accelerated the replacement of older small (9-15 inch screen) sets, designed for only one channel. ${ }^{\text {lxxxii }}$ 
Market saturation should have made it easier to predict demand and smooth production seasonality, using production planning, dealer 'stocking' schemes, and the introduction of new models during off-peak periods. However, such methods proved futile in the face of unanticipated changes in government restrictions. In late 1959 manufacturers were aware that market saturation would produce a fall in demand and had planned output accordingly. However, the re-imposition of credit restrictions served to build up stocks before these lower production targets came into effect, forcing manufacturers to cut production to uneconomic levels. As a 1960 BREMA memorandum noted: 'Production schedules... call for large-scale investment planned well ahead, and cannot be cut-back suddenly without very serious disruption... throughout the chain of supply... ${ }^{\text {Ixxxiii }}$ The memorandum claimed that, unless government took immediate steps, the financial stability of manufacturers and distributors would be imperilled, undermining the industry's ability to compete internationally.

Over the year to $30^{\text {th }}$ September 1960 manufacturers' stocks of televisions rose from 157,000 to 636,000. ${ }^{\text {lxxiv }}$ Total stocks (for manufacturers and dealers) at the end of August 1960 were estimated at 1.2 million units, represented $£ 23$ million of capital at ex-factory prices for manufacturers stocks and $£ 16$ million at wholesale prices for dealers' stocks (excluding Purchase Tax paid or due to be paid). The majority now represented the previous year's models, thus depressing new model production. ${ }^{\text {lxxxv }}$

This crisis marked a major watershed in the industry. ${ }^{\text {lxxxvi }}$ One important casualty was Ekco, one of the largest British TV manufacturers, with an outstanding record for technical excellence and design success. Yet an accumulation of stocks during 1960 (accentuated by an unwillingness to ruthlessly cut back production) precipitated financial difficulties that marked its demise as an independent entity. As their Financial Controller noted, 'the swing from a sellers to a buyers' market almost overnight... [resulted] in grave over production by the industry and the group with consequent slashing of production and prices all round... Large 
redundancies in factory personnel also played havoc with the factory situation.... ${ }^{\text {lxxxvii }}$ Ekco was forced into a merger with Pye, while in the following year another major producer, Ultra, failed as a result of the squeeze (being acquired by Thorn). ${ }^{1 \times x x v i i i}$

\section{IV}

The literature on consumer durables distinguishes between 'entertainment' and 'laboursaving' durables. Labour-saving durables are generally found to have much slower diffusion rates than entertainment durables (reflecting the lower priority households attach to them); together with slower product cycles and obsolescence. ${ }^{\text {lxxxix }}$ In order to examine the extent to which HP restrictions and Purchase Tax changes impacted on UK sales across consumer durables, we look at the largest class of entertainment durables, televisions, and a representative high-ticket household durable, washing machines. Most previous economic analysis of stop-go impacts on consumer durables has focused on the car market. ${ }^{\mathrm{xc}}$ However, impacts of HP restrictions are inherently much more difficult to model for cars than for televisions or white goods. In addition to a substantial business demand, most new private cars were purchased using bank loans, or by using the well-developed trade-in market to cover much or all of the deposit. Moreover, prior to 1955 shortages of supply for the home market created long waiting lists for new cars. ${ }^{\text {xci }}$

\section{[Figure 1 near here]}

Figure 1 shows the evolution of monthly unit sales of televisions from January 1951 to December 1965 and maps the dates of changes in Purchase Tax rates and HP introductions, changes, and withdrawals. The data show both substantial seasonal variation and a clear trend in annual sales. Total, rather than HP, sales are chosen both for reasons of data availability and because we are principally interested in the impact of policy on affected industries, rather than 
just on their HP trade. We examine both changes in minimum HP deposit requirements and maximum contract terms. ${ }^{\text {xcii }}$ We further include the Purchase Tax rate and, from its introduction in February 1956, the 'rental minimum down-payment' (the number of months' rental that had to be paid up-front for rented TV's, a measure introduced to deter evasion of the HP restrictions). Estimates of the number of people who could receive a television signal are also included (separately for the BBC and ITV as, while ITV transmitters covered territories already served by the BBC, the launch of ITV is known to have boosted set diffusion).

Unit sales in the current period, $q_{t}$, are modelled as being determined by their prior values $\left(q_{t 1}\right.$ and $\left.q_{t 2}\right)$, the average price of a television in the two previous periods $\left(p_{t 1} p_{t 2}\right)$, quarterly cycle movements of the economy (measured by quarterly consumers' expenditure in current market prices) $)^{\mathrm{x} c i i i}, y_{t_{1}}$ and $y_{t 2}$, and the key variables of interest - the series of events listed above relating to changes in HP restrictions, taxes, transmission coverage, plus variables capturing annual trends - via a year trend and coverage $\left(x_{t}\right)$, dummies for each month:

$$
q_{t}={ }_{0}+{ }_{1} q_{t 1}+{ }_{2} q_{t 2}+{ }_{3} p_{t 1}+{ }_{4} p_{t 2}+{ }_{5} y_{t 1}+{ }_{6} y_{t 2}+{ }_{k=1}^{K}{ }_{k} \text { Event }_{t}+{ }_{l=1}^{L}{ }_{l} x_{t}+{ }_{m=1}^{M}{ }_{l} \text { Month }_{t}+{ }_{t}
$$
where ${ }_{t}$ is the error term.

Event dummies for introductions, changes, and removals of the three stop-go instruments - HP restrictions (minimum deposits and maximum contract terms), changes in Purchase Tax rates; and rental minimum down payments - enable us to look at impacts in specific months. While the timings of Purchase Tax changes and HP restrictions do not regularly coincide, in half of the 12 instances where minimum HP deposits, or maximum contract terms, are adjusted, both are changed simultaneously. Changes in rental minimum down payments also mainly coincide with changes in maximum contract terms. 
The results, shown in Table 2, examine the impact on changes in sales. ${ }^{\text {xciv }}$ Eighteen stop-go event dates are highlighted. We follow Bain's analysis of television diffusion in including a further event, the Queen's coronation on June $2^{\text {nd }} 1953$, with a dummy variable that covers the three prior months. ${ }^{\text {xcv }}$ There is also a Purchase Tax reduction in April 1953, but we cannot identify its impact due to the conflating effects of the coronation.

The results provide consistent indications that tightening restrictions had substantial negative impacts on monthly television sales, while relaxing restrictions boosted sales. Seven of the eighteen stop-go interventions have well-determined impacts, while all remaining interventions, bar one, have impacts that could not be determined at conventional significance levels. The only intervention with a significant impact in the opposite direction to that predicted is the October 1955 Purchase Tax increase. This occurred in the month after the launch of ITV, which has a large and well-defined impact on sales (a 58.3\% rise) and appears to have a continuing positive impact into October, conflating the impact of a relatively modest (10\%) Purchase Tax rise. Impacts on sales values are considerable, ranging between a 32\% reduction following the February 1956 restrictions and a $41 \%$ expansion following the removal of HP restrictions in July 1954 . We also find a substantial impact for the coronation $(29.2 \%$ for the three prior months). Both this and the strong coefficient for the ITV launch are consistent with earlier analysis of TV diffusion, by Bain. ${ }^{\mathrm{xcvi}}$ We test for unit roots using an augment Dickey Fuller test, including constant and trend components (given the data clearly has a trend). We are able to reject the hypothesis of a unit root at all common significance levels. Similarly, the Breusch-Godfrey test implies that we have no problems of serial correlation. ${ }^{\text {xcvii }}$

\section{[Table 2 near here]}

Of the two classic high-ticket labour-saving household durables of this era, washing machines and refrigerators, we selected electric washing machines for analysis. As Figure 2 shows, washing machines displayed a broadly similar diffusion pattern to refrigerators, but 
diffused somewhat faster (as refrigerators were an outlier among labour-saving durables in terms of their high purchase and running costs). Furthermore, unlike refrigerators, monthly unit sales data for electric washing machines are available for the full period of analysis. Unfortunately monthly data on the value of sales are not available until 1957, though annual data are available from 1954, enabling us to compose an annual price index. As sales and values are very highly correlated (99.5\%) they provide close proxies in this case.

[Figure 2 near here]

We again include minimum HP deposit terms, maximum HP contract lengths, and Purchase Tax rates. Figure 3 shows the evolution of these variables and maps the dates of changes in Purchase Tax rates and HP introductions, changes, and withdrawals. While they are notably less variable than TV sales, there is nevertheless substantial seasonal variation and a clear trend in annual sales.

\section{[Figure 3 near here]}

The findings, in Table 3, are qualitatively similar to those for televisions. All interventions show the expected sign, where significant. The specification test provides no indication that the model suffers from unit roots or serial correlation. Our results thus indicate that HP and Purchase Tax changes impacted substantially on consumer demand for both entertainment and labour-saving durables, in line with official perceptions that the restrictions were having the desired effect. This is consistent with the literature for motor vehicles, which finds that the tightening of HP restrictions was associated with declining sales and that British output volatility exceeded that of other European countries. ${ }^{\text {xcviii }}$

[Table 3 near here] 
This study supports the view that there were strong continuities in the fundamental economic priorities of the Treasury and, particularly, the Bank of England, between the 1920s and 1950s, based around supporting sterling and the City. ${ }^{x c i x}$ Analysis of an extensive volume of Treasury, Bank of England, and other policy files indicates that the main driver of policy was the defence of sterling at its current exchange rate, with near-full employment viewed as a political constraint on this aim. ${ }^{c}$ The underlying objective of this policy, restoring the City's leading international role, proved successful. Yet, just as the long-term growth of the City and other sectors associated with Britain's international role (such as oil and defence-related engineering) cannot be explained without taking account of their consistent prioritisation by government, the flip side of this policy - active discrimination against other sectors - should not be ignored in accounts of their decline.

Financial retrenchment hit all manufacturing sectors, through periodic restrictions on bank lending and capital issues, though its impact was particularly severe on the consumer durables industries, that were forced to bear most of the burden of adjustment in consumer demand. We have shown not only that this policy inflicted severe direct damage on these industries, but that some problems commonly seen as root causes of their declining competitiveness - such as deteriorating industrial relations and failures to reach minimum efficient scale or maintain capacity output - were at least exacerbated by the restrictions.

The Bank of England and Treasury had successfully pushed a policy that essentially involved favouring one group of sectors - associated with banking, finance, and international trade, at the expense of another - associated with manufacturing and, particularly, high ticket consumer durables. This had a number of long-term consequences for British economic development, boosting the growth of the City and the wider London area at the expense of Britain's provincial regions and increasing Britain's reliance on a relatively narrow base of internationally-orientated service industries. 
Our findings also qualify the depiction of the 1950s as an era of "affluence" for the working-classes. Formal rationing, which effected all sections of the population, was replaced by a less transparent system of credit rationing, that impacted most severely on those sections of society without bank or department store accounts. By limiting access to credit, government severely restricted the access of lower income families to some of the key status-related goods of the post-war era, such as cars, televisions and white goods, and effectively forced such households to bear much of the burden of financial retrenchment.

\section{Footnote references}

Ali, M., 'Hire purchase controls and the demand for cars in the post war United Kingdom', Journal of Economic Studies, 1 (1965), pp. 88-96.

Adeney, M., The Motor Makers. The Turbulent History of Britain's Car Industry (1988).

Allen, W.A., Monetary Policy and Financial Repression in Britain, 1951-59 (Basingstoke, 2014).

Bain, A.D., The Growth of Television Ownership in the United Kingdom since the War. A Lognormal Model (Cambridge, 1964).

Booth, A., 'Inflation, expectations, and the political economy of Conservative Britain, 19511964', Historical Journal, 43 (2000), pp. 827-47.

Bowden, S., and Offer, A., 'The technological revolution that never was: gender, class, and the diffusion of household appliances in interwar England, in V. De Grazia (ed), The Sex of Things. Gender and Consumption in Historical Perspective (Berkeley, 1996), pp. 244-274.

BREMA, The UK Market for Television Receivers 1946-1978 (1979). 
Brittan, S., Steering the Economy. The Role of the Treasury (1969).

Broadberry, S., The Productivity Race. British Manufacturing in International Perspective, 1850-1990 (Cambridge, 1997).

Broadberry, S. and Leunig, T., `The impact of government policies on UK manufacturing since 1945', Foresight, Government Office for Science, Future of Manufacturing Project, Evidence Paper 2 (2013)

https://www.gov.uk/government/uploads/system/uploads/attachment_data/file/277158/ep2government-policy-since-1945.pdf

Cairncross, A., Years of Recovery. British Economic Policy 1945-51 (1985).

Croham, L., 'Were the instruments of control for domestic economic policy adequate', in F. Cairncross and A. Cairncross (eds), The Legacy of the Golden Age. The 1960s and their Economic Consequences (1992), pp. 81-109.

Cuthbertson, J.R., 'Hire purchase controls and fluctuations in the car market', Economica , 73 (1961), 125-36.

Dow, J.C.R., Major Recessions: Britain and the World, 1920-1995 (Oxford, 1998).

Dunnett, P.J.S., The Decline of the British Motor Industry. The Effects of Government Policy 1945-1979 (1980).

Edgerton, E., Warfare State. Britain 1920-1970 (Cambridge, 2006).

Eloranta, J., 'Armaments and the economy', in R. Floud, J. Humphries, and P. Johnson (eds), The Cambridge Economic History of Modern Britain. Voume II. 1870 to the Present (Cambridge, 2014), pp. 279-301. 
Foreman-Peck, J., Bowden, S., and McKinlay, A., The Britsih Motor Industry (Manchester:, 1995).

Frankland, M., Radio Man. The Remarkable Rise and Fall of C. O. Stanley (2002).

Geddes K., and Bussey, G., The Setmakers. A History of the Radio and Television Industry (1991).

Gracie, H., and Duncan, I., Historical Record of the Census of Production 1907 to 1970 (1968).

Green, E.H.H., 'The influence of the City over British economic policy c. 1880-1960', in

Harris, R, Seldon, A., and Naylor, M., Hire Purchase in a Free Society (1959).

Hatton, T.J. and Chrystal, K.A., 'The budget and fiscal policy', in N.F.R. Crafts and N.W.C. Woodward, The British Economy since 1945 (Oxford, 1991), pp. 89-140.

Ingham, G., Capitalism Divided? The City and Industry in British Social Development (Basingstoke, 1984).

Kareken, J.H., 'Monetary policy', 68-103 in R.E. Caves (ed), Britain's Economic Prospects (Washington DC, 1968).

Matthews, R.C.O., 'The role of demand management', in A. Cairncross (ed), Britain's Economic Prospects Reconsidered (1971), pp. 13-35.

Middleton, R., 'Struggling with the impossible: sterling, the balance of payments and British economic policy, 1949-72', in A. Arnon and W. Young (eds.), The Open Macromodel: Past, Present, and Future (2002), pp. 103-54. 
Newton, S., 'Keynesianism, sterling convertibility, and British reconstruction 1940-1952,' in

R. Michie and P. Williamson, The British Government and the City of London in the Twentieth Century (Cambridge, 2004), pp. 257-275.

National Economic Development Office, Cyclical Fluctuations in the United Kingdom Economy (1976).

Newey, W.K., and West, K.D., 'A simple, positive semi-definite, heteroskedasticity and autocorrelation consistent covariance matrix', Econometrica 55 (1987), pp. 703-708. Oliver, F.R., The Control of Hire Purchase (1961).

Opie, R., 'The making of economic policy', in H. Thomas (ed.), Crisis in the Civil Service (1968), pp. 53-82.

Prais, S., Productivity and Industrial Change. A Statistical Study of Manufacturing Industry in Britain, Germany and the United States (Cambridge, 1981).

Pratten, C. and Silberston, A., 'International comparisons of labour productivity in the automobile industry, 1950-1965,'Bulletin of the Oxford University Institute of Economics \& Statistics, 29, 4 (1967), pp. 373-394.

Rees, J., Refrigeration Nation. A History of Ice, Appliances, and Enterprise in America (Baltimore, 2013).

Schenk, C., Britain and the Sterling Area. From Devaluation to Convertibility in the 1950s (1994).

Schenk, C., The Decline of Sterling. Managing the Retreat of an International Currency, 1945-1992 (Cambridge, 2010).

Self, R., British Foreign and Defence Policy Since 1945 (Houndsmills, 2010). 
Strange, S., Sterling and British Policy. A Political Study of an International Currency in Decline (1971).

Silberston, A., 'Hire purchase controls and the demand for cars', Economic Journal, 73 (1963), pp. 32-53.

Soloway, A.M. 'Economic aspects of the British purchase tax', Journal of Finance, 9 (1954), pp. 188-208.

Tiratsoo N. and Tomlinson, J., The Conservatives and Industrial Efficiency, 1951-1964.

Thirteen Wasted Years? (1998).

Tomlinson, J., Public Policy and the Economy since 1900 (Oxford, 1990).

Whiting, A., 'An international comparison of the instability of economic growth', Three Banks Review, 109 (1976), pp. 26-46.

Wilson, T., 'Instability and growth: an international comparison, 1950-65', in D.H. Aldcroft and P. Fearson, Economic Growth in Twentieth-Century Britain (1969), pp. 184-195.

Wood, J., Wheels of Misfortune. The Rise and Fall of the British Motor Industry (1988).

Woodward, N., The Management of the British Economy 1945-2001 (Manchester, 2004).

Wray, M. 'Household durables and the "squeeze"', Westminster Bank Review (August 1957), pp. 5-9.

\section{Official publications}

UK, Board of Trade, Report on the Census of Production for 1963 (1969).

UK, CSO, Monthly Digest of Statistics (1951-1955). 
UK, Inland Revenue, Reports of the Commissioners of Her Majesty's Inland Revenue, years ending 31st March 1960-1966 (1960-1966).

UK, Ministry of Labour, Ministry of Labour Gazette (1951-1966).

UK, Parliament, Committee on the Working of the Monetary System, Report (Cmd. 827 of 1959). 
Table 1: Ferranti's estimates of costs and profits at various levels of TV output

\begin{tabular}{|l|r|r|r|r|}
\hline Annual production (units) & $\mathbf{2 3 , 0 0 0}$ & $\mathbf{4 7 , 0 0 0}$ & $\mathbf{7 0 , 5 0 0}$ & $\mathbf{9 4 , 0 0 0}$ \\
\hline \begin{tabular}{|l|r|r|r|}
\hline Costs/profits (as \% of total revenue) \\
Materials:
\end{tabular} & & & \\
\hline Cabinet & 18.2 & 16.7 & 16.0 & 15.6 \\
\hline Cathode Ray Tube* & 14.2 & 13.5 & 13.1 & 12.8 \\
\hline Other & 29.2 & 28.0 & 27.2 & 26.7 \\
\hline Total & 61.6 & 58.2 & 56.3 & 55.1 \\
\hline Other production costs & 26.8 & 21.4 & 18.8 & 17.2 \\
\hline Sales \& distribution** & 19.6 & 15.7 & 13.7 & 12.6 \\
\hline Total costs & 108.0 & 95.3 & 88.8 & 84.9 \\
\hline Profit/loss & -8.0 & 4.7 & 11.2 & 15.1 \\
\hline SOurc:
\end{tabular}

Source: Manchester Museum of Science and Industry Archives, Ferranti collection, 1996/10/1/7/409, notes regarding unit costs of television sets, 26th Feb. 1953 (with later notes added, 11th January 1955).

Notes: Data for 23,000 unit production based on production in the 1952 calendar year. Figures for higher outputs based on American data.

* Cathode ray tube figure for 1952 is not the actual cost incurred, but what the tubes could have been purchased for (more cheaply) from Mullard.

** Data for 23,000 units includes a reserve of $£ 15,000$ for bad debts over and above $£ 5,000$ of bad debts actually incurred. 
Table 2. Impacts of "Stop-Go" Policies on Sales of Televisions (January 1951 - December 1965)

\begin{tabular}{|c|c|c|c|c|}
\hline & & & & t-stat \\
\hline Events & Purchase Tax (raised) & Apr-51 & -0.129 & $(0.84)$ \\
\hline & HP restrictions (introduced) & Feb-52 & 0.052 & $(0.53)$ \\
\hline & Coronation & Mar to May-53 & 0.292 & $(2.32)$ \\
\hline & HP restrictions (removed) & Jul-54 & 0.407 & (3.36) \\
\hline & HP restrictions (introduced) & Feb-55 & -0.011 & $(0.14)$ \\
\hline & HP (minimum raised) & Jul-55 & -0.117 & $(1.20)$ \\
\hline & ITV introduction & Sep-55 & 0.583 & $(11.40)$ \\
\hline & Purchase Tax (raised) & Oct-55 & 0.188 & $(1.91)$ \\
\hline & HP restrictions \& rental minimum (raised) & Feb-56 & -0.310 & $(4.81)$ \\
\hline & HP restrictions \& rental minimum (reduced) & Sep-58 & 0.201 & $(4.41)$ \\
\hline & HP restrictions \& rental minimum (reduced) & Oct-58 & 0.182 & $(1.85)$ \\
\hline & Purchase Tax (reduced) & Apr-59 & 0.168 & $(2.05)$ \\
\hline & HP restrictions \& rental minimum (introduced) & Apr-60 & -0.095 & $(0.98)$ \\
\hline & HP (maximum raised) & Jan-61 & 0.105 & $(1.05)$ \\
\hline & Purchase Tax (reduced) & Mar-61 & -0.013 & $(0.14)$ \\
\hline & Purchase Tax (reduced) & Apr-62 & -0.007 & $(0.08)$ \\
\hline & Purchase Tax (reduced) & Jan-63 & 0.122 & $(1.20)$ \\
\hline & HP minimum restrictions (raised) \& rental minim & Jun-63 & 0.217 & $(2.49)$ \\
\hline Coverage & Coverage (BBC mns) & & 0.008 & $(1.61)$ \\
\hline & Coverage (ITV mns) & & 0.003 & $(1.07)$ \\
\hline Lagged value, price, and & $\log \left(\right.$ sales $\left._{\mathrm{t}-1}\right)$ & & 0.611 & $(6.50)$ \\
\hline household expenditure & $\log \left(\right.$ sales $\left._{t-2}\right)$ & & 0.090 & $(0.99)$ \\
\hline & $\log \left(\right.$ price $\left._{t-1}\right)$ & & 0.417 & $(0.83)$ \\
\hline & $\log \left(\right.$ price $\left._{t-2}\right)$ & & -0.482 & $(0.89)$ \\
\hline & $\log \left(\right.$ Household Expenditure $\left._{\mathrm{t}-1}\right)$ & & 1.411 & $(0.62)$ \\
\hline & $\log \left(\right.$ Household Expenditure $\left._{\mathrm{t}-2}\right)$ & & -0.226 & $(0.11)$ \\
\hline Year (trend) & & & -0.079 & $(0.87)$ \\
\hline Constant & & & -4.063 & $(0.51)$ \\
\hline Monthly dummies & & & YES & \\
\hline $\mathrm{R}^{2}$ & & & 0.86 & \\
\hline Prob $>F$ & & & 0.000 & \\
\hline Breusch-Godfrey Test $\left(\mathrm{X}^{2}\right.$ & & & 2.361 & \\
\hline Augumented Dickey-Fulle & er Test & & -5.118 & \\
\hline $\mathrm{N}$ & & & 178 & \\
\hline
\end{tabular}

Sources: Source: BREMA, UK Market.

Notes: 1. Estimated using OLS. 2. Augmented Dickey-Fuller test estimated incorporates trend and a constant. 
Table 3. Impacts of "Stop-Go" Policies on Sales of Electric Washing Machines (January 1951 - December 1965)

\begin{tabular}{|c|c|c|c|c|}
\hline & & Coeff & & tat \\
\hline Events & Purchase Tax (raised) & Apr-51 & 0.124 & $(1.43)$ \\
\hline & HP restrictions (introduced) & Feb-52 & -0.531 & $(6.37)$ \\
\hline & Purchase Tax (reduced) & Apr-53 & 0.306 & $(4.82)$ \\
\hline & HP restrictions (removed) & Jul-54 & 0.183 & (2.04) \\
\hline & HP restrictions (introduced) & Feb-55 & -0.136 & (2.51) \\
\hline & HP restrictions (raised) & Jul-55 & -0.194 & (2.99) \\
\hline & Purchase Tax (raised) & Oct-55 & 0.067 & $(1.23)$ \\
\hline & HP restriction (min deposit raised) & Feb-56 & 0.287 & (4.47) \\
\hline & Purchase Tax (reduced) & Apr-58 & 0.275 & (4.93) \\
\hline & HP (minimum reduced) & Sep-58 & 0.011 & $(0.25)$ \\
\hline & HP (minimum removed) & Oct-58 & 0.003 & $(0.05)$ \\
\hline & Purchase Tax (reduced) & Apr-59 & 0.468 & (6.75) \\
\hline & HP restrictions (introduced) & Apr-60 & 0.192 & (3.52) \\
\hline & HP maximum (raised) & Jan-61 & 0.280 & $(4.56)$ \\
\hline & Purchase Tax (raised) & Jul-61 & 0.035 & $(0.64)$ \\
\hline & Purchase Tax (reduced) & Apr-62 & 0.060 & $(0.90)$ \\
\hline & HP minimum (raised) & Jun-65 & -0.236 & (2.94) \\
\hline & HP maximum (reduced) & Jul-65 & -0.266 & $(3.70)$ \\
\hline Lagged value and & $\log \left(\Delta\right.$ sales $\left._{\mathrm{t}-1}\right)$ & & -0.233 & $(2.50)$ \\
\hline household expenditure & $\log \left(\Delta\right.$ sales $\left._{\mathrm{t}-2}\right)$ & & -0.130 & $(1.34)$ \\
\hline & $\log \left(\right.$ sales $\left._{t-1}\right)$ & & -0.100 & (2.11) \\
\hline & $\log \left(\right.$ Household Expenditure $\left.{ }_{t-1}\right)$ & & 2.642 & (1.59) \\
\hline & $\log \left(\right.$ Household Expenditure $\left.{ }_{t-2}\right)$ & & -2.933 & $(1.65)$ \\
\hline Year (trend) & & & 0.025 & $(0.36)$ \\
\hline Constant & & & 1.387 & $(0.23)$ \\
\hline $\mathrm{R}^{2}$ & & & 0.57 & \\
\hline Prob $>F$ & & & 0.000 & \\
\hline Breusch-Godfrey Test ( $\mathrm{X}^{2}$ & & & -5.107 & \\
\hline Augumented Dickey-Full & er Test & & 1.023 & \\
\hline $\mathrm{N}$ & & & 178 & \\
\hline
\end{tabular}

Sources: Modern Records Centre, Coventry; Mss 20/F3/E3/10/1, data provided to FBI by H.A. Furness, Hoover Ltd, 30 June 1960; Bank of England Archives, C40/725, 'Hire purchase and other instalment credit', September 1958, internal report, n.d., c. September 1958; UK, Inland Revenue, Reports of the Commissioners of Her Majesty's Inland Revenue, years ending 31st March 1960-1966 (1960-1966).

Notes: see table 2. 


\section{Appendix Table 1: Purchase tax rates and hire purchase /other credit regulations on}

televisions, 1946-1960

\begin{tabular}{|c|c|c|}
\hline Period & $\begin{array}{l}\text { Purchase } \\
\operatorname{tax}(\%)\end{array}$ & HP controls \\
\hline June 1948 - March 1951 & 33.33 & None \\
\hline April 1951 - Jan. 1952 & 66.67 & None \\
\hline Feb. 1952 - March 1953 & 66.67 & $\begin{array}{l}33.3 \% \text { deposit, maximum repayment period } 18 \text { months; or zero deposit, } \\
\text { maximum repayment period nine months. }\end{array}$ \\
\hline April 1953 - June 1954 & 50.00 & $\begin{array}{l}33.3 \% \text { deposit, maximum repayment period } 18 \text { months; or zero deposit, } \\
\text { maximum repayment period nine months. }\end{array}$ \\
\hline July 1954 - Jan. 1955 & 50.00 & None \\
\hline Feb. 1955 - June 1955 & 50.00 & 15\% deposit, maximum 24 months; zero deposit, maximum 9 months. \\
\hline July 1955 - Sept. 1955 & 50.00 & 33.3\% deposit, maximum 24 months; zero deposit, maximum 9 months \\
\hline Oct. 1955 - Jan. 1956 & 60.00 & 33.3\% deposit, maximum 24 months; zero deposit, maximum 9 months \\
\hline Feb. 1956 - Aug. 1958 & 60.00 & 50\% deposit, maximum 24 months; zero deposit, maximum 9 months. \\
\hline Sept. 1958 & 60.00 & 33.3\% deposit, maximum 24 months, zero deposit, maximum 9 months \\
\hline Oct. 1958 - March 1959 & 60.00 & None \\
\hline April 1959 - March 1960 & 50.00 & None \\
\hline April 1960 - Dec. 1960 & 50.00 & $20 \%$ deposit, maximum 24 months; zero deposit, maximum 9 months \\
\hline Jan. 1961 - June 1961 & 50.00 & $20 \%$ deposit, maximum 36 months; zero deposit, maximum 9 months \\
\hline July 1961 - March 1962 & 55.00 & $20 \%$ deposit, maximum 36 months; zero deposit, maximum 9 months \\
\hline April 1962 - May 1962 & 45.00 & $20 \%$ deposit, maximum 36 months; zero deposit, maximum 9 months \\
\hline June 1962 - Dec. 1962 & 45.00 & $10 \%$ deposit, maximum 36 months. \\
\hline Jan. 1963 - May 1965 & 25.00 & 10\% deposit, maximum 36 months. \\
\hline June 1965 & 25.00 & $15 \%$ deposit, maximum 9 months. \\
\hline July 1965 - Jan. 1966 & 25.00 & 15\% deposit, maximum 30 months. \\
\hline
\end{tabular}

Source: see Figure 1. Notes: 'Zero deposit' terms refer to non-HP credit transactions. 


\section{Appendix Table 2: Purchase tax rates and hire purchase regulations on electric washing}

machines, 1951-1965

\begin{tabular}{|c|c|c|}
\hline Period & $\begin{array}{c}\text { Purchase } \\
\operatorname{tax}(\%)\end{array}$ & HP controls \\
\hline June 1948 - March 1951 & 33.33 & None \\
\hline April 1951 - Jan. 1952 & 66.67 & None \\
\hline Feb. 1952 - March 1953 & 66.67 & 33.3 per cent deposit, maximum repayment period 18 months \\
\hline April 1953 - June 1954 & 50.00 & 33.3 per cent deposit, maximum repayment period 18 months \\
\hline July 1954 -Jan. 1955 & 50.00 & None \\
\hline Feb. 1955 - June 1955 & 50.00 & 15 per cent deposit, maximum repayment period 24 months \\
\hline July 1955 - Sept. 1955 & 50.00 & 33.3 per cent deposit, maximum repayment period 24 months \\
\hline Oct. 1955 - Jan. 1956 & 60.00 & 33.3 per cent deposit, maximum repayment period 24 months \\
\hline Feb. 1956 - March 1958 & 60.00 & 50 per cent deposit, maximum repayment period 24 months \\
\hline April 1958 - August 1958 & 30.00 & 50 per cent deposit, maximum repayment period 24 months \\
\hline Sept. 1958 & 30.00 & 33.3 per cent deposit, maximum repayment period 24 months \\
\hline Oct. 1958 - March 1959 & 30.00 & None \\
\hline April 1959 - March 1960 & 25.00 & None \\
\hline April 1960 - Dec. 1960 & 25.00 & 20 per cent deposit, maximum repayment period 24 months \\
\hline Jan. 1961 - June 1961 & 25.00 & 20 per cent deposit, maximum repayment period 36 months \\
\hline July 1961 - March 1962 & 27.50 & 20 per cent deposit, maximum repayment period 36 months \\
\hline April 1962 - May 1962 & 25.00 & 20 per cent deposit, maximum repayment period 36 months \\
\hline June 1962 - May 1965 & 25.00 & 10 per cent deposit, maximum repayment period 36 months \\
\hline June 1965 & 25.00 & 15 per cent deposit, maximum repayment period 36 months \\
\hline July 1965 - Dec. 1965 & 25.00 & 15 per cent deposit, maximum repayment period 30 months \\
\hline
\end{tabular}

Source: see Figure 2. 
Figure 1: Monthly unit sales of televisions, January 1951 to December 1965 (thousands)

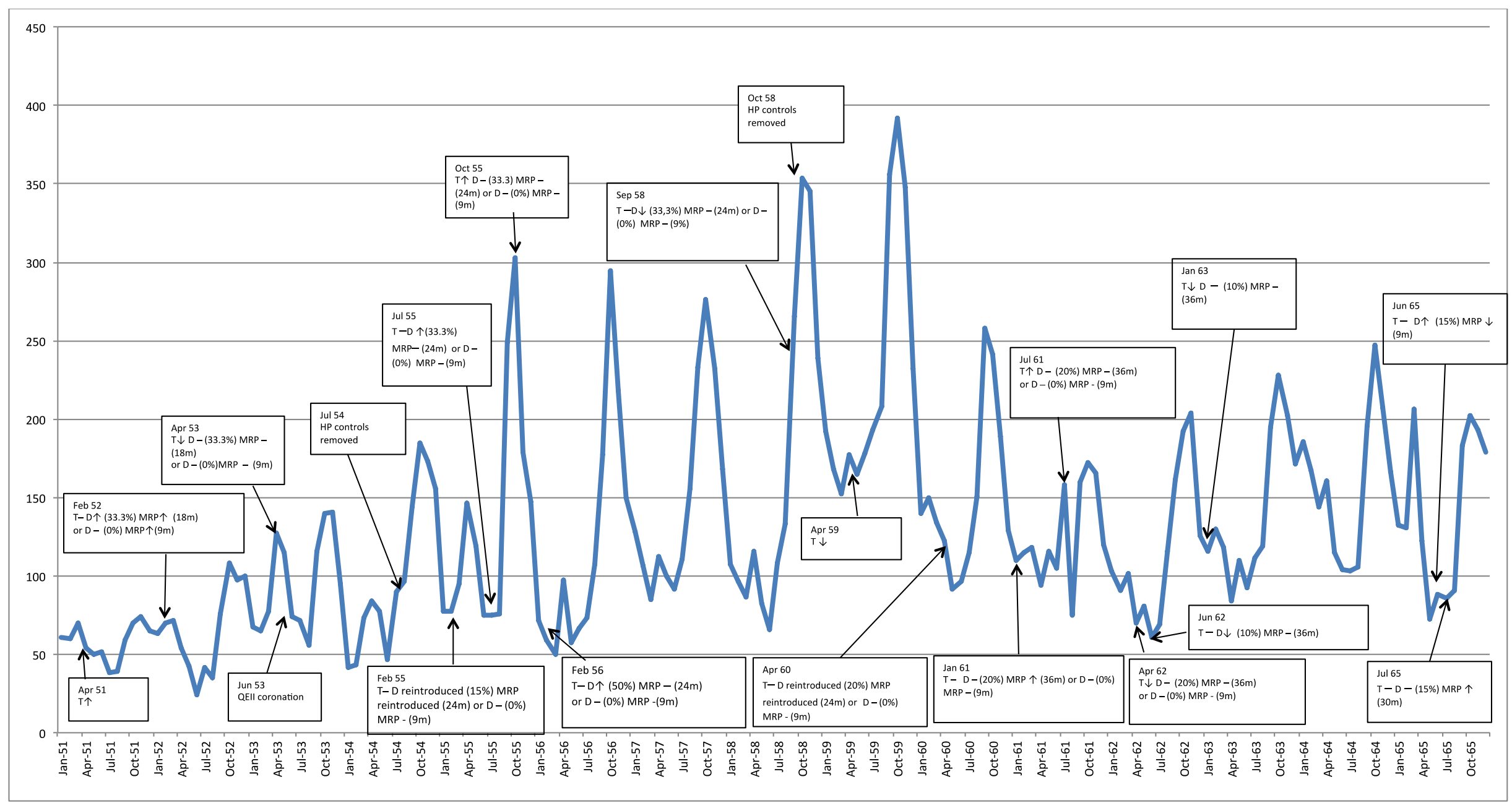

Sources: see Table 2.

Notes: $\mathrm{T}=$ purchase tax; $\mathrm{D}=$ deposit rates; $\mathrm{MP}=$ Maximum repayment - the length of the period in months is provided in brackets. Arrow indicated increases and decreases in deposits, repayment periods and '-' indicates where there is no change. Details on each intervention are located in Appendix Table 1. 
Figure 2: Diffusion of washing machines, refrigerators, and televisions (percentage of homes wired for electricity) in England \& Wales, 19461965

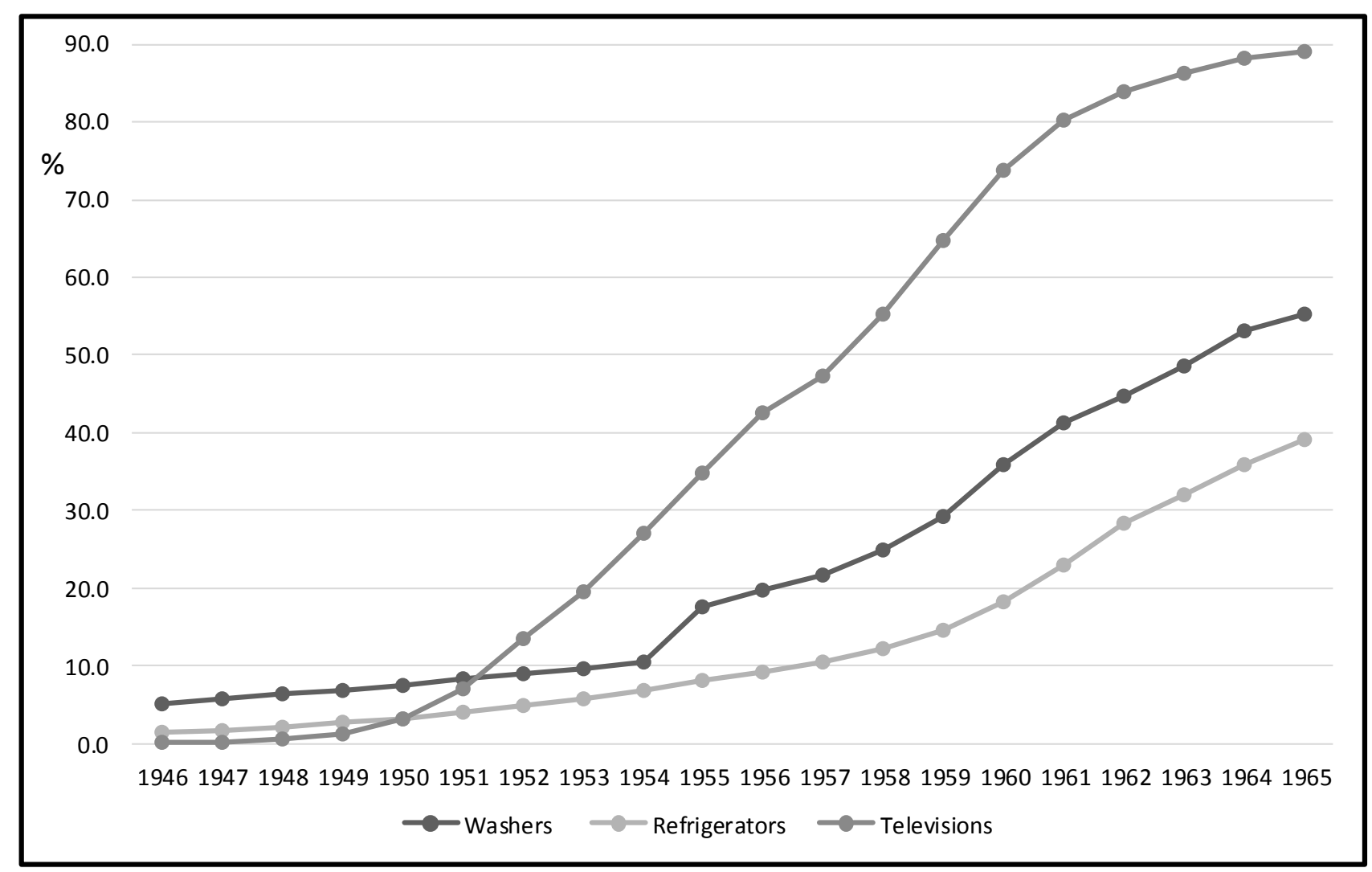

Source: Bowden and Offer, ‘ technological revolution', pp. 745-746. 
Figure 3: Monthly unit sales of washing machines, January 1951 - December 1965 (thousands)

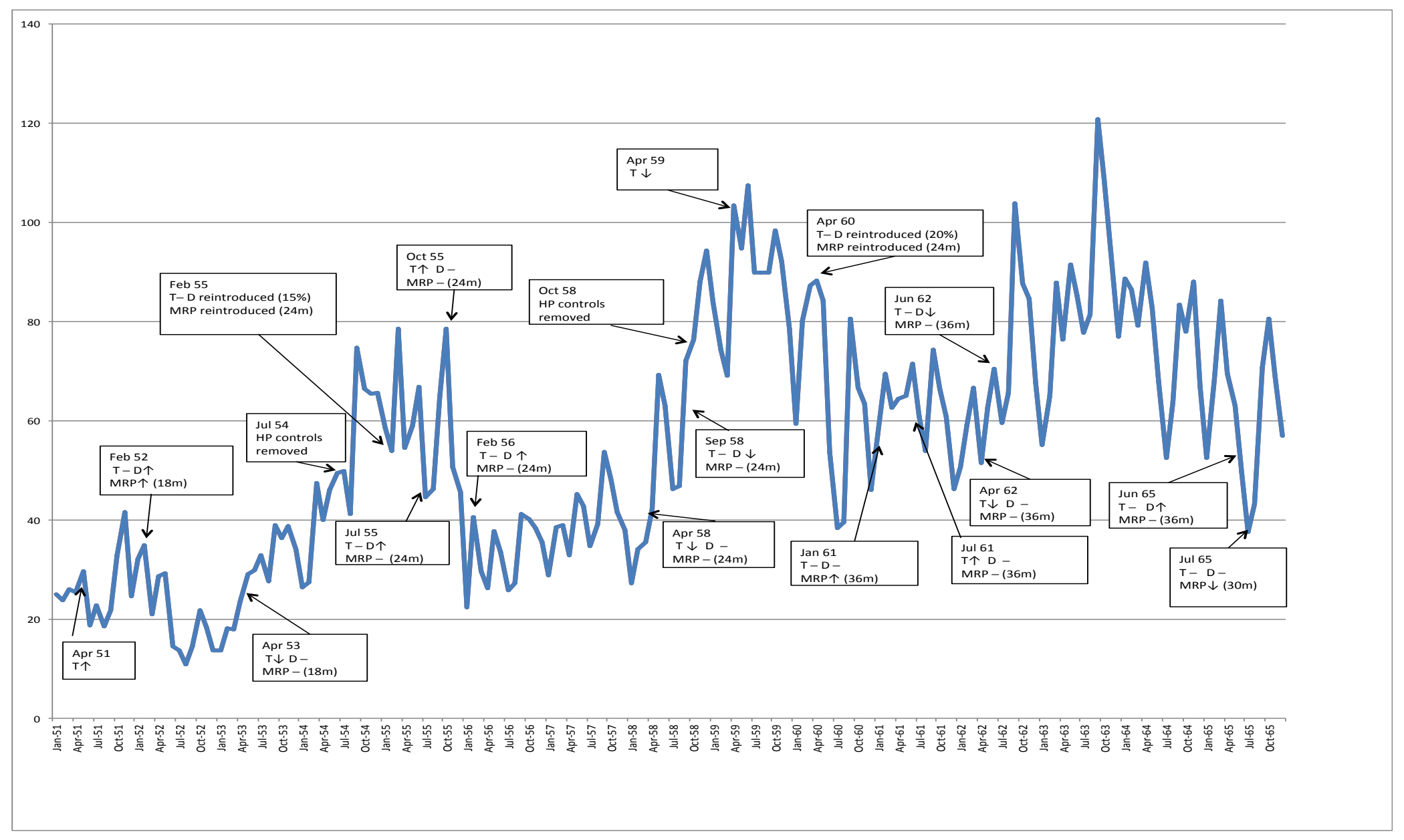

Sources: see Table 3. Notes: See Figure 1. 


\begin{abstract}
' We thank the staff of the Bank of England Archives; Manchester Museum of Science and Industry Archives; Modern Records Centre, University of Warwick; the National Archives, Kew; National Media Museum, Bradford; and Southend Central Museum, for generous assistance. Thanks are also due to Linda Arch, Chris Brooks, Mark Casson, Sean O'Connell, Catherine Schenk, participants at the Economic History Conference (Wolverhampton, 2015), and three anonymous referees, for comments on earlier drafts and material. Any errors are ours.
\end{abstract}

\footnotetext{
ii Bank of England Archives (hereafter BEA), C40/724, 'Hire Purchase', memorandum by Humphrey Mynors, 30 August 1957.
}

iii See, for example, Committee on the Working of the Monetary System, Report, para. 472; Brittan, Steering the Economy, pp. 112 \& 137-38; Matthews, 'Role of demand management'; Wilson, 'Instability and growth';

Whiting, 'International comparison'; National Economic Development Office, Cyclical Fluctuations;

Woodward, Management, pp. 81-82; Dow, Major Recessions, p. 260; Croham, 'Were the instruments', pp. 812; Tomlinson, Public Policy, pp. 238-61; Broadberry and Leunig, 'Impact', pp 40-42.

iv TNA, T230/660, Working Party on Hire Purchase Controls, draft report, $22^{\text {nd }}$ October 1963. Net output data are from UK, Board of Trade, Report on the Census, reports 49, p. 5; 58, p. 3; 59, p. 3, 62, p. 3, 63, p. 3; 131, p. 10. This estimate is based on the motor vehicle; motorcycle, pedal cycle, etc.; refrigeration machinery; radio and electronic apparatus; domestic electrical appliances; and furniture product classes.

${ }^{v}$ See, for example, TNA, T230/660, Working Party on Hire Purchase Controls, draft report, 22 ${ }^{\text {nd }}$ October 1963.

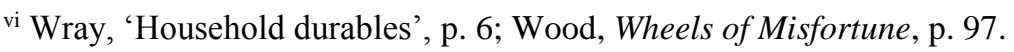

vii See Foreman-Peck, Bowden, and Mckinlay, British Motor Industry, pp. 89-164.

viii See Gracie and Duncan, Historical Record, pp. 34-37.

${ }^{\text {ix }}$ See Self, British Foreign and Defence Policy, pp. 29-39; Edgerton, Warfare State, p. 68; Eloranta,

‘Armaments’, pp. 291-93; Middleton, ‘Struggling', pp. 106-9; Tomlinson, Public Policy, p. 250; Schenk,

Britain, p. 113. Schenk (pp. 88-112) argues that while officials perceived capital outflows to the Sterling Area as an onerous burden, they overestimated the negative impact.

${ }^{x}$ Strange, Sterling, p. 231; Ingham, Capitalism Divided?, pp. 204-6; Tiratsoo and Tomlinson, Conservatives, pp. 22-25.

xi Opie, ‘Making of economic policy'; Booth, ‘Inflation’; Middleton, ‘Struggling’, pp. 110-111. 
xii Soloway, 'Economic aspects', pp. 188-95.

xiii Tiratsoo and Tomlinson, Conservatives, p. 29.

xiv Woodward, Management, p. 69.

${ }^{\mathrm{xv}}$ Cairncross, Years of Recovery, pp. 240-41.

xvi Soloway, 'Economic aspects', p. 204.

xvii Cited in Oliver, Control of Hire Purchase, p. 178.

xviii TNA 230/660, Working Party on Hire Purchase Controls, draft report, 22 October 1963.

xix BEA, C40/722, 'The post-war growth of instalment credit in the United Kingdom', paper prepared by Samuel Katz for Board of Governors, Federal Reserve system, 18 Sept. 1956, p. 29.; C40/720, 'Hire Purchase’, note, initialled H.M.N., to Chief Cashier, Bank of England, 4 January 1952.

${ }^{x x}$ TNA, T233/1587, 'Control of credit for hire purchase', memorandum, $28^{\text {th }}$ May 1954 . The reference to the 'right goods' presumably means those more representative of total consumer expenditure.

${ }^{x x i}$ Kareken, 'Monetary policy'.

xxii Tomlinson, Public Policy, p. 241; Matthews, 'Role of demand management', p. 14. An alternative policy of a managed floating currency was considered in early 1952 , under the 'ROBOT' plan. This was a crisis response to pressure on Britain's reserves and demonstrated an even stronger prioritisation of sterling's international role - as maintaining external confidence in sterling under the managed float was deemed to require severe deflation, Newton, 'Keynesianism', pp. 270-222.

xxiii BEA, G1/97, Cobbold - Butler, 30 $0^{\text {th }}$ July 1952, cited in Allen, Monetary Policy, p. 44.

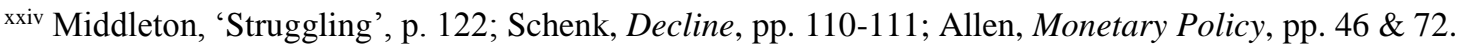

${ }^{x x v}$ TNA, T233/1587, 'Control of credit for hire purchase', memorandum, 28 May 1954. See also Committee on the Working of the Monetary System, Report, para. 433; Hatton and Chrystal, 'Budget and fiscal policy', p. 68. xxvi TNA, T229/725, 'Purchase tax and the restriction of hire purchase', note by A. M. Jenkins, 5 March 1953. xxvii Oliver, Control of Hire Purchase, p. 80. 'Furniture' also includes domestic hardware and ironmongery; radio and TV sets includes sales of valves.

xxviii Britain, Steering the Economy, pp. 122-4; TNA, T258/437, draft Board of Trade evidence on Hire Purchase for the Radcliffe Committee, 6 September 1957.

xxix BEA, C40/722, 'The post-war growth of instalment credit in the United Kingdom', paper prepared by Samuel Katz for Board of Governors, Federal Reserve system, 18 Sept. 1956, pp. 2 \& 13-17. 
${ }^{\text {xxx }}$ Modern Records Centre, Coventry (hereafter MRC); Mss 20/F3/E3/10/1, FBI Committee on Hire Purchase, 'Government regulation of hire purchase contracts', memorandum, 18 March 1957.

${ }^{\text {xxi }}$ BEA, C40/725, 'Hire purchase and other instalment credit, September 1958', internal report, n.d., c.

September 1958; G14/157, 'Hire purchase and other instalment credit, December 1958, internal report, n.d., c. December 1958; Britain, Steering the Economy, p. 138.

xxxii Brittan, Steering the Economy, pp. 139-41.

xxxiii Source: Silberston, `Hire purchase controls’, p. 51, based on Board of Trade data.

xxxiv TNA, T230/660, 'The consumer durables industries and the BREMA memorandum', undated note, c. October 1960.

xxxv TNA, BT 258/1059, 'Background information. H.P. Debt', note by Board of Trade Statistics Department, 9 May 1960; 'Hire Purchase debts', note by Statistics Dept., 10 May 1960; T230,660, 'Hire purchase terms control', Treasury note, annexed to documents dated 21 June 1960.

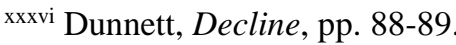

xxxvii TNA, BT233/1586, ‘The permanent control of hire purchase terms', memorandum, n.d., c. 1954.

xxxviii MRC; Mss 20/F3/E3/10/1, 'Hire purchase controls', memorandum, 29 June 1960.

xxxix Wray, 'Household durables', p. 5.

${ }^{x l}$ See, for example, TNA, T230/660, Working Party on Hire Purchase Controls, draft report, 22 October 1963.

xli Ibid; Geddes and Bussey, Setmakers, pp. 332-334. Foreman-Peck, Bowden, and McKinlay, British

Motor Industry, pp. 198-200, argue that stop-go impacted negatively on investment in the automobile industry, though mainly indirectly, by depressing profit performance.

xlii TNA, T230/2310, note on representations from the Society of Motor Manufacturers and Traders, $23^{\text {rd }}$ February 1961.

xliii TNA, BT213/72, Ford Motor Co., 'Purchase tax on motor vehicles', memorandum submitted to Board of Trade, February 1957.

xliv TNA, T229/724, Society of Motor Manufacturers and Traders, 'Purchase tax', memorandum, $24^{\text {th }}$ September 1952.

xlv TNA, T229/724, 'Purchase tax on motor cars', note, signature illegible, October 1952; 'Motor economics', Economist (15 October 1938), pp. 119-20. 
${ }^{x l v i}$ BEA, C40/690, 'Short-term working in the motor industry', unsigned note, $5^{\text {th }}$ March 1956. For a chronology of HP and Purchase Tax restrictions in automobiles, see Foreman-Peck, Bowden, and McKinlay, British Motor Industry, pp. 197-198.

xlvii TNA, BT213/72, Ford Motor Co., 'Purchase tax on motor vehicles', memorandum submitted to Board of Trade, February 1957.

xlviii TNA, T230/2310, note on representations from Society of Motor Manufacturers and Traders, $23^{\text {rd }}$ February 1961.

xlix Dunnett, Decline, p. 63

${ }^{1}$ TNA, T230/2310, note on representations from Society of Motor Manufacturers and Traders, 23 February 1961.

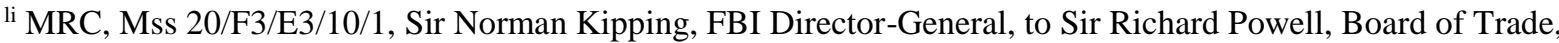
$15^{\text {th }}$ September 1960.

lii TNA, BT213/72, Ford Motor Co., 'Purchase tax on motor vehicles', memorandum submitted to Board of Trade, February 1957.

liii Wray, 'Household durables', p. 7.

${ }^{\text {liv }}$ MRC, M.ss 200/F/3/E5/9/3, memorandum from Joint Committee of Retail Trade Associations on Purchase Tax Rebate to FBI Committee on Tax-Paid stocks, 30 ${ }^{\text {th }}$ August 1952; minutes of meeting of FBI Purchase Tax Panel, 24 ${ }^{\text {th }}$ March 1953.

${ }^{\text {lv }}$ MRC; Mss 20/F3/E3/10/1, 'The demand for domestic electrical appliances', memorandum by Stanley Stewart, Director, BEAMA, July 1960.

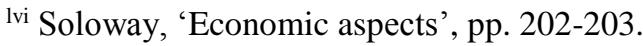

lvii TNA, T258/437, draft Board of Trade evidence on Hire Purchase for Radcliffe Committee, 6 September 1957.

lviii MRC, Mss 200/f/3/e3/10/4, 'Hire purchase controls - radio and television products. Special considerations', BREMA memorandum, September 1960.

lix TNA, T230/660, note by R. L. Hall, 13 October 1960.

1x TNA, BT258/437, 'Hire purchase control on the furniture industry', draft memorandum by President, Board of Trade, 9 July 1958.

lxi MRC, Mss 292/660/91/2, 'Hire Purchase', Labour Party Study Group on Control of Industry memorandum, March 1958; TNA, BT103/728, 'House of Commons: Hire purchase', memorandum, 10 $0^{\text {th }}$ March 1956. 
Ixii MRC, Mss 20/F3/E3/10/1, 'Hire purchase controls', unsigned memorandum, 29 June 1960.

Ixiii Adeney, Motor Makers, pp. 210-213; Foreman-Peck, Bowden, and McKinlay, British Motor Industry, pp. 165, 179-181, \& 203; Wood, Wheels of Misfortune, p. 97.

${ }^{1 x i v}$ Source: Ministry of Labour Gazette, various issues.

${ }^{1 x v}$ See Pratten and Silberston, “International comparisons'; Prais, Productivity, pp. 156-9; Foreman-Peck, Bowden, and McKinlay, British Motor Industry, pp. 93-95 \& 131.

Ixvi Broadberry, Productivity Race, p. 318.

lxvii See Foreman-Peck, Bowden, and McKinlay, British Motor Industry, pp. 124-7.

Ixviii Ibid, p. 201.

${ }^{\text {lxix }}$ Sue Bowden and Paul M. Turner, `stop-go, hire purchase and the British motor vehicle industry, paper presented at the 1993 meeting of the Quantitative Economic History Study Group, University of York, September 1993, cited in Foreman Peck, Bowden, and McKinlay, British Motor Industry, p. 201.

${ }^{1 \times x}$ Harris, Seldon, and Naylor, Hire Purchase, p. 54.

${ }^{1 \times x i}$ Rees, Refrigeration, p. 179.

lxxii TNA, BT233/1586, 'The permanent control of hire purchase terms', memorandum, n.d., c. 1954; T230/660, Working Party on Hire Purchase Controls, draft report, 22 October 1963; TNA, BT258/477, note by Board of Trade, I.M. 2, 9 Sept. 1957.

lxxiii Manchester Museum of Science and Industry Archives, Ferranti collection, 1996/10/1/7/409, notes regarding unit costs of television sets, 26th Feb. 1953, with later notes added, 11th January 1955.

${ }^{\text {Ixxiv }}$ NMM, EMI Papers, Box 10, unsigned memorandum on EMI's position in the TV sector, 19 November 1952.

lxxv T229/735, 'Radio and television sales’ draft paper for Economic Policy Committee by A.R. Low, 26 July 1952; NMM, EMI Papers, Box 10, 'Radio and Television Market' unsigned EMI memorandum, 16 June 1952. Earnings data (for April 1952) are from UK, Department of Employment and Productivity, British Labour Statistics: Historical Abstract 1886-1968 (1971), p. 101.

Ixxvi TNA, T229, 735, 'Note on radio and television set production', unsigned, 7 July 1952.

Ixxvii TNA, BT258/458, 'Further investigation into the effect of S.I. 121, 1952, the hire purchase order, on sales of goods covered thereby', report by Consumer Needs Branch, December 1953.

Ixxviii BEA, EID9/39, unsigned note by Statistics Office, Bank of England, 21 ${ }^{\text {st }}$ December 1954.

Ixxix Geddes and Bussey, Setmakers, p. 351. 
${ }^{\text {Ixxx }}$ Geddes and Bussey, Setmakers, pp. 351-2.

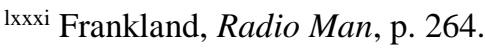

lxxxii MRC, Mss 200/f/3/e3/10/4, 'Hire purchase controls - radio and television products. Special considerations', BREMA memorandum, September 1960.

lxxxiii MRC, Mss 200/f/3/e3/10/4, 'Hire purchase controls', BREMA memorandum to the Treasury, September 1960.

${ }^{\text {lxxiv }}$ MRC, Mss 20/F3/E3/10/1, data supplied to FBI by BREMA, January 1961.

${ }^{\text {lxxxv }}$ MRC, Mss 200/f/3/e3/10/4, 'Hire purchase controls', BREMA memorandum to the Treasury, September 1960.

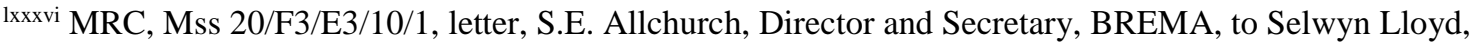
Chancellor of the Exchequer, $12^{\text {th }}$ January 1961.

Ixxxvii Southend Central Museum, Ekco archives, SOUMS 2009/357, 'A financial report on the trading activities of the Ekco group for the year ended 31 ${ }^{\text {st }}$ March 1961, by the Director and Financial Controller'.

lxxxviii Geddes and Bussey, Setmakers, pp. 353-6.

lxxxix Bowden and Offer, 'Technological revolution', p. 250.

${ }^{x c}$ For example, Cuthbertson, 'Hire purchase'; Silberston, 'Hire purchase'; Ali, 'Hire purchase'.

${ }^{\text {xci }}$ Ibid.

${ }^{\text {xii }}$ In cases where there were two minimum deposit bands, with the higher band having a longer maximum contract term, we use the term that is consistent with the lower minimum deposit band.

xciii Sources: 1951-1954, Personal expenditure on consumers' goods and services, current market prices, CSO, Monthly Digest of Statistics (1951-1955); 1955-1965, Household final consumption expenditure, current prices, series ABPB, http://www.ons.gov.uk/ons/datasets-and-tables/data-selector.html?cdid=ABJQ\&cdid

$=\mathrm{ABPB} \& \mathrm{cdid}=\mathrm{ABQI} \& \mathrm{cdid}=\mathrm{ABTE} \& \mathrm{cdid}=\mathrm{ABTF} \&$ dataset $=$ ukea $\&$ table $-\mathrm{id}=6.2$

${ }^{\text {xciv }}$ We also have unit sales data. However the correlation between value and quantity sold is very high (0.994), so not surprisingly the results are very similar.

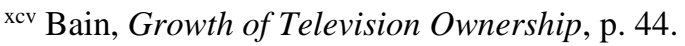

${ }^{\text {xcvi }}$ Ibid, p. 42.

xcvii We also implemented the Newey-West model and found qualitatively similar outcomes. Newey and West. 'Simple, positive,' pp. 703-708.

xcviii Sue Bowden and Paul M. Turner, 'Stop-go, hire purchase and the British motor vehicle industry,' paper presented at a meeting of the Quantitative Economic History Group, University of York, September 1993, cited 
in James Foreman-Peck, Sue Bowden, and Alan McKinlay, The Britsih Motor Industry (Manchester:

Manchester U.P.), 1995), p. 201; Silberston, 'Hire purchase'.

xcix Opie, 'Making of economic policy'; Green, 'Influence of the City', p. 203; Brittan, Steering the Economy, pp. 112 \& 137-38; Middleton, 'Struggling', pp. 110-112.

${ }^{c}$ We examined all files for the period under review with titles relating to hire purchase or purchase tax policy, or the main consumer durables sectors. These included 64 TNA files, mainly in the; BT 11, 70, 94, 103, 213, 241, 258, and 263; CAB 129; HO 244 and 256; LAB 17; POWE 14, 29, and 43; PREM 11; T 229, 230, 233, 234 and 320 classes. We also examined ten Bank of England files: ADM/12, C40/690, C40/720-725, EID 9/39. G14/157. 